\title{
Teachers' Perspectives towards the Implementation of Constructivism in Teaching EFL at Salahaddin University
}

\author{
Qismat M. Zahawi ${ }^{1}$, Fatimah R. Hasan Al Bajalani ${ }^{2}$ \\ ${ }^{1}$ Department of English, College of Basic Education, Salahaddin University, Erbil, Kurdistan Region - F.R. Iraq \\ ${ }^{2}$ Department of English, College of Languages, Salahaddin University, Erbil, Kurdistan Region - F.R. Iraq
}

\begin{abstract}
The aim of this study is to elicit Kurdish EFL teachers' perspectives on constructivism and its implementation at university level. To obtain the needed data, a questionnaire is administered to 49 EFL teachers at Salahaddin University. According to the most significant results of the research, the Kurdish EFL teachers in general have positive perspectives toward constructivism as a teaching and learning approach. However, their agreement with the implementation of the different principles of constructivism varied and the agreement percentage for the items ranged from $89.39 \%$ to $73.47 \%$. It is worth mentioning that the current study is an extract from a PhD dissertation that investigates the effectiveness of implementing the principles of constructivism in the Kurdish context.
\end{abstract}

Index Terms - Constructivism, Kurdish EFLteachers, Perspective

\section{INTRODUCTION}

We are in the midst of a period in history when authorities and educational stakeholders seek to initiate major changes of their educational system. As for Kurdistan Region, there are progressive reform attempts including the adoption of national educational standards in the Reform movement and most recently, the introduction of Bologna Process into the Higher Education system. Initiating any reform movement can be tied with the fact that teachers act as important agents of change in any educational system.

In this respect, Tan (2016, p.5) asserts that constructivism exerts an exalting influence on education and is "often discussed and lauded as an alternative to the traditional transmission approach". He further proceeds that constructivist instruction is growingly considered as a modern option to engage the students through active participation and situated learning.

There is a dire need to change the prevalent conventional teaching model in Kurdistan Region, especially in the field or teaching English as a Foreign Language (EFL) and give birth to an unfailing succession of changes. Throughout this process of change, teachers' perspectives become crucial and are expected to play a key role in changing their institutions. Hence, the current study seeks to advance this cause by determining significant aspects of current thinking of Kurdish EFL teachers regarding the implementation of constructivist approach to teaching and learning. Accordingly, this study aims to answer the following question:

What are the Kurdish teachers' perspectives towards utilizing constructivism in teaching EFL?

Based on the results of this study, one can determine the readiness of Kurdish EFL teachers for implementing constructivism as a cornerstone of any future reform attempt.

\section{Delineating Constructivism}

The word constructivism is derived from the word construction. Constructivism, a theory of learning, emphasizes that meaningful and real learning does not result from what teachers say or what learners repeat. As its name indicates, its cornerstone is that learners construct and build meaning within their own minds based on their experiences and prior knowledge (Jordan et al, 2008). Furthermore, this construction of knowledge is influenced by two factors: individual (the learners' own methods, way of understanding, and experiences to build knowledge) and social (the learners' environment and the society in which they live). Fox (2001, p.25) describes constructivism as a "metaphor for learning", where he likens the acquisition of knowledge to a process of building or construction.

In the same token, Candy (1991), as cited in Benson (2011, p.38), depicts constructivism as a cluster of approaches which share a core belief that knowledge cannot be taught but it is

Journal of University of Human Development

Volume 5 No. 3(2019); DOI: 10.21928/juhd.v5n3y2019.pp28-35

Regular research paper: Published 8 July 2019

Corresponding author's e-mail: qismat.hussin@su.edu.krd

Copyright (02019 Qismat M. Zahawi, Fatimah R. Hasan Al Bajalani . This is an open access article distributed under the Creative Commons

Attribution License (CC BY-NC-ND 4.0) 
constructed on the part of learners themselves.

In general, constructivism is often thought of by authors such as Fosonot (2005, p.279) as a theory of learning and not a theory about teaching. This theory is descriptive in nature in the sense that it does not prescribe rules for teaching. He proceeds "but when one analyzes the theory, one can begin to formulate a reformed practice that supports rigor, empowerment, and the construction of genuine understanding".

Richards and Schmidt (2010, p.123) view constructivism as "a social and educational philosophy" built on the following main tenets:

- Knowledge is actively constructed by learners and not passively received.

- Cognition is an adaptive process that organizes the learner's experiential world.

- All knowledge is socially constructed.

To finish, it can be asserted that constructivism is a learning theory that emphasizes two core points: firstly, students actively control their own knowledge and learning by integrating their own experience to the new situations they encounter, rather than being fed by teachers. Secondly, it prepares students to be capable in socially required skills.

\section{COnStRUCTIVISM IN EDUCATION}

Vadeboncoeur (1997) accentuates the need for a theory of education that enables teachers to deal with the many questions, issues, and challenges encountered in educating people in a way that will empower them to become powerful and dedicated knowledge constructors and knowledge users. He further asserts that constructivism seems to be a satisfactory solution since it is now compelling recognition and a growing number of educators are rethinking about constructivist ideas and trying to implement its principles within their everyday practice. For this reason, constructivism has come to dominate much of educational discourse and has reached high popularity in the 1980s and 1990s.

Henry (2002) asserts that constructivism owes a substantial debt to the new social studies recommendations of the 1960s and 1970s. These studies emphasized open-ended questions, student-centered inquiry, and primary source materials. We find that these techniques foreshadow many of the ideas and techniques of the constructivist movement. Kaufman (2004) asserts that constructivism has come into prominence in recent years as a dominant paradigm in education and has resulted in a major intellectual impact on the development of pedagogy.

Mahmud (2013) affirms that constructivism made the first breakthrough against conventional teaching and put forth the idea of learner-oriented teaching and then reflective thoughts. It came up with a wider vision of the role of the teacher and clearer strategies for developing teaching and learning.

Young (2014) considers Dewey as the chief forerunner of constructivism. Dewey developed a practical approach to education embracing a triangular relationship among the individual, the community, and the external world where learning takes place. Similarly, Mahmud (2013) asserts that
Dewey's reflective school of thought includes a clear hint and a pointing finger to the primary idea of applied constructivism which promotes students' knowledge construction and personal reflection on experience.

Hinojosa (2015) posits that the constructivist viewpoint on education is supported by the contributions of different psychological theories, among which are: the theory of cognitive schemas, the psychogenetic Piagetian approach, the Ausubelian meaningful learning, the Vygotskian sociocultural psychology, Bandura's social cognitive theory in addition to some instructional theories. Although the authors of these theories hold different theoretical stances, they all agree with the principle of the significance of constructive activity of students in their learning. In spite of having various versions of constructivism, there is a consensus among authors that constructivism represents a significant shift in the concerns of education by placing the student's efforts to understand in the center of the educational enterprise.

Correspondingly, Astawa et al (2017) consider constructivism as one of the theories that can be successfully used to address the learning process according to 21 st century evolving needs. It emphasises upon the importance of studentscentered learning activities and reflecting on experiences towards the quality of learning.

\section{Previous Studies Reviewed}

The researcher reviewed relevant studies to investigate teachers' perspectives regarding constructivism. In this regard, two studies have been carried out to identify teachers' perspective towards the use of constructivist theory in teaching and learning. Bakla (2011) studied teachers' views on constructivism in Turkish primary EFL classes. He noticed that primary school English teachers in Turkey seem to have come to an understanding of constructivism in an overall sense and admit the utility and use of the theory. However, they still encounter serious challenges in terms of practice due to the shift in emphasis from knowledge as a product to knowing as a process.

An important pedagogical implication to draw from this study is that teachers need to be empowered through in-service training on how to put constructivist principles into practice in the classroom.

Correspondingly, another study (Kaymakamoğlu, 2014) was conducted to investigate teachers' perspective regarding constructivist theory. The results seemed to be broadly similar and congruent to those of the previous one, and the teachers' beliefs were aligned with the constructivist view of learning and teaching within the context of Cyprus Turkish secondary state schools.

\section{THE PRINCIPLES OF CONSTRUCTIVISM}

Before analysing the results of the questionnaire, it is instructive to shed light on the main principles of constructivism. Constructivism, as a modern theory of learning, 
has many principles that enable the students to learn by using what they already know to construct new understandings and be lifelong learners. The key principles of constructivist teaching and learning according to (Wilson and Cole, 1991; Brooks and Brooks, 1999; and Fernando and Marikar, 2017) are as follows:

\section{Principle 1}

Learning is an active process

Kudryashova et al (2016) assert that active learning methods are often associated with constructivism. They further affirm that some scholars hold the belief that "constructivist learning is a more appropriate name for active learning".

\section{Principle 2}

Learners actively engage in their knowledge building based on prior experiences.

Cey (2001) proclaims that active learning inherently implies a "doing". Hence, a constructivist-directed classroom is expected to be based on performance and persistence on the part of the students. They are inspired to generate their own ideas and knowledge through execution and expansion of their prior knowledge. The emphasis of instruction must be directed towards the creation of meaning and understanding while encountering new information or new contexts. Therefore, students must be given opportunities to be active in ways that will promote profound learning which results from acting in situations. Accordingly, we can regard active learning as an amalgam of activities that causes knowledge to be constructed by the student.

\section{Principle 3}

Knowledge is socially constructed. Cooperative work is encouraged.

Rowell and Palmer (2007) describe cooperative learning as a teaching strategy "where constructivism reaches its pinnacle". They hold the belief that cooperative learning fosters the process of "meaning-making" in the classroom because of the active nature of the assignments.

Similarly, Schell and Janicki (2013, p.28) describe the cooperative model of teaching and learning as "an offspring of and closely related to the constructivist model".

\section{Principle 4}

Multiple representation of content is favoured

Researchers who show adherence to constructivism concentrate on the use of multiple modes of learning and on the importance of encountering multiple perspectives. This is based on their belief that using multiple modes of representation paves the way for students to view the same content through diverse modes such as visual and auditory. Consequently, this would broaden their thinking, allowing them to evaluate alternative solutions to problems as a means of testing their own understanding (Chieu, 2005).

\section{Principle 5}

Assessment is authentic and interwoven with teaching. Dynamic assessment is encouraged to assess students learning in the context of teaching.

Sengupta (2016) maintains that assessment is viewed from opposing poles by behaviourists and constructivists. Behaviourists assume that "knowledge exists separately from the learner; therefore, students work to accumulate knowledge rather than to construct it". They consider content as the only component of the curriculum upon which assessment is based. This type of assessment encourages rote learning or "mugging" regardless of any intellectual skill. The questions are closely connected to the material covered in the course and students tend to memorize and send out without any deep understanding. On the other hand, constructivists regard this view as an "incomplete and short-sighted position". They believe that curriculum consists of four parts: content, process, product, and environment. This view implies that how students learn, how they show what they have learned, and the circumstances in which they learn are as essential as what they learn. Accordingly, this paradigm necessitates an alternative means of testing to assess student learning. This alternative assessment is a process by which teachers collect information that they will use to make instructional decisions with a view to adjusting their practice to better address their students' needs.

\section{Methodology}

\section{Participants}

The target population for teachers' questionnaire composed of EFL teachers who teach English as a foreign language in the colleges of Languages, Education, and Basic Education (92 teachers) at Salahaddin University-Erbil. However, the final size of the teachers who actually answered the questionnaire dropped from 92 to 49 teachers. The teachers received both a soft copy of the questionnaire (via email) and a hard copy (via their departments).

\section{Data Collection Instrument}

The researcher used a questionnaire to get the required data. The design of the questionnaire was determined by the basic framework of the study which was based on the principles of constructivism (as described above), consulting a large number of sources and scientific journals, and insights from the literature reviewed concerning the pedagogical implications of implementing these principles in teaching.

In the light of what have been discussed earlier, it can be said that constructivism is the assemblage of specific principles that have a long history in teaching and which can be implemented by every single teacher whether he/she has awareness about constructivism or not. Hasan (2014, pp. 95-96) carried out a research to assess the use of socio-cultural approach (also called social constructivism) at Salahaddin University based on a 
checklist. He deduced that "some of the thoughts and the actions of socio-cultural approach are in a way or another implemented". That is to say, teachers occasionally used some of these principles in their teaching; however, their implementation was not "methodological" and that the sociocultural theory was not recognized as a defined theory, as he described. Accordingly, their teaching was not aligned with socio-cultural approach to teaching (social constructivism) due to the fact that the approach was unfamiliar to them. Therefore, the researcher based her questionnaire on Hasan's argument that teachers intuitively use some of these principles in their teaching.

The researcher sought the teachers' perspectives towards implementing constructivist principles in teaching EFL to their students. She used teachers' questionnaire to collect data from Kurdish EFL teachers concerning their use of constructivist principles in their teaching. The questionnaire consisted of 23 Likert scale statements which were divided into four dimensions: teachers' beliefs, assessment tools, cooperative work, and the materials.

\section{Questionnaire Reliability}

Before commencing the actual experiment, a pilot test with ten respondents for each questionnaire (ten teachers) was carried out. The significance of the piloting lied in the fact that it revealed some difficulties concerning wrong wording, the level of difficulty of words for the respondents, and the clarity of the instructions.

Generally, Cronbach alpha is one of the most widely used methods for determining internal reliability. To check internal consistency of the two questionnaires, the Cronbach's alpha coefficient was computed and the Cronbach's alpha value for the teachers' questionnaire was calculated as .75 indicating an acceptable reliability of these tools. The result is listed in Table (1).

Table (1) Reliability analysis

Teachers' questionnaire - reliability analysis

\begin{tabular}{|c|c|}
\hline Cronbach's Alpha & Number of items \\
\hline .75 & 23 \\
\hline
\end{tabular}

After ensuring that the questionnaire enjoyed satisfactory reliability and validity, the final version was employed for the main study.

\section{DATA ANALYSIS AND DISCUSSION}

The quantitative results obtained from the questionnaire about teacher beliefs and perspectives ( 23 items) are discussed below (see appendix 1):

The first domain in the teachers' questionnaire is allotted for 'teachers' beliefs' and it comprises five items:

Regarding the first item, it is found that $85 \%(\mathrm{M}=4.41)$ of the teachers agree that learners need to be active participants in the learning process. This high percentage of agreement reveals the teachers' expression of the necessity of engaging students and enhancing their participation through the use of different activities.

As for item (2), 81\% (M=4.18) of the teachers expressed their agreement that maximizing teacher-students interaction reduces their shyness and matures their personality. This indicates that most of the teachers enjoy having mutual interaction with their students since it improves students' academic achievement and social skill. Undoubtedly, teachers who have positive interaction with their students create classroom environments more supportive to learning that addresses students' developmental, emotional and educational needs.

Concerning item (3), 84\% (M=4.20) of the teachers showed agreement that it is important to consider students' voice and choice in selecting materials/activities. This response denotes that the majority of the teachers hold the view that they do not need to be the ultimate decision-makers regarding material/activity selection. Besides, it reveals that most of the teachers encourage the students to explore their passions and believe that taking students' voice into account offers them a powerful range of incentives and makes students feel honoured for their ideas and opinions.

Being an important aspect of a constructivist classroom, playing the role of partner and facilitator of knowledge with their students seems to be readily accepted by teachers. In item (4), it is evident that the majority of the teachers $87 \%(M=4.41)$ prefer to act the role of partner and facilitator. This shows the teachers' willingness to create an educational environment where their students can build their own knowledge with appropriate teacher's support and guidance.

We notice that in item (5) 84\% (M=4.33) agree with it and believe that assigning projects to students can reveal their uniqueness. This high percentage of agreement shows the teachers' acquaintance with their students' individual differences in terms of their learning styles and interests.

The teachers' response to the first domain of the questionnaire (teachers' beliefs) reveals the fact that the majority of the teachers possess open pedagogical thinking since they have shown their agreement with the concepts of student autonomy and independent development of skills, using active learning strategies, and taking students' voice into consideration. This can be counted as a positive indication on the part of Kurdish EFL teachers because it demonstrates that they are ready to exert effort in making their classes absolutely utile.

The second domain of the questionnaire is related to using different types of assessment tools. It consists of five items. The first item in this domain is:

As for item (6), the majority of the respondents $89 \%$ $(\mathrm{M}=4.47)$ strongly agree that assessing students through dynamic assessment tools rather than traditional tests is stimulating for students. This high degree of agreement can be regarded as the teachers' thumbs up for using authentic assessment tools. The teachers believe that utilising new and 
authentic assessment activates their students because it saves them from the routine of being assessed by the same way over and over, i.e., it keeps their enthusiasm alive. Besides, authentic assessment urges students to synthesizing information instead of retelling information, which in itself is an interest arousing process.

As a matter of fact, this response on the part of the teachers shows that they are enthusiastic to change the traditional assessment methods that are outdated and do not cope with the new developments in the field of education, which in turn, reveals their familiarity with the new methods of assessment and their enthusiasm to adopt these new assessment methods if the Higher Education system allows and guides them to implement these.

Item (7) received $85 \%(M=4.27)$ of the teachers' agreement; teachers believe that employing dynamic assessment discloses the students' efforts in learning outside their classrooms. The teachers' belief resides in the fact that authentic assessment empowers students to have ownership of their own learning and demonstrate their understanding in unique ways that clearly disclose the various endeavours they make to learn, e.g., searching online sources, making student hand-made materials, assessing oneself and peers, etc.

As for item (8), a shared agreement $83 \%(\mathrm{M}=4.16)$ is detected among the teachers who hold the belief that dynamic assessment can enrich students' learning experience. This belief originates from the teachers' satisfaction that the use of authentic assessment Ignites students' creativity and urges them to construct their meanings through digging deep rather than shallow recalls of information.

Regarding item (9), the percentage of teachers' agreement is $73 \%(M=3.67)$. This result reinforces the result of item No6 where the majority of the teachers approved that assessing students through traditional assessment reduces their inspiration because they feel that their efforts and skills have not been assessed adequately. However, the rest of the teachers (27\%) disagree with the item and still believe in the effectiveness of the traditional assessment. This can be ascribed to being used to employ traditional assessment and common disadvantages of alternative assessment like: subjectiveness, being time consuming and difficult to administer.

Concerning item (10), 78\% (M=3.9) agree that dynamic assessment is flexible and provides students with opportunities to progress. Teachers think that the provision of abundant opportunities by using authentic assessment makes the process a pliant one and leads to better investment of students' potential.

However, and similar to the previous item, we find that more than $20 \%$ of the teachers still show allegiance to conventional methods of assessment and cannot easily abdicate their old method and conform to the new ones.

Generally speaking, positive perspectives towards the use of authentic methods of assessment have been detected in the teachers' responses, which can be regarded as a promising hint.

The third domain of teachers' questionnaire is concerned with cooperative learning, which is regarded as the thread for all students' learning in constructivist classes. It consists of six items:
As for item (11), 84\% (M=4.24) agree that group work can increase students' social interaction skills. The teachers apparently seem to support and encourage cooperative learning in their classes. It follows from this that they agree with the idea that cooperative learning enables the students to work together and develop interpersonal relationships. By building up social interaction skills, it becomes easy to create a learning community that supports individual students and values diversity.

In item (12), 86\% (M=4.31) of the teachers agree that group work enables students to exchange experiences and share ideas. This agreement can be attributed to the point that cooperative learning provides greater opportunities for students to debate, analyse, synthesise, reflect on experiences (whether their own experience or their peers'), and reach joint decisions.

As for item (13), 86\% (M=4.35) of the teachers agree that group work leads students to be autonomous and responsible for their own learning. This reflects the teachers' belief that cooperative learning, if implemented in the right spirit, would place equal load on students' shoulders and enable them to share responsibility and be accountable for their own learning.

Regarding item (14), 86\% (M=4.31) of the teachers expressed their agreement that group work helps students diagnose their own strengths and weaknesses. This is due to their belief that cooperative work includes debating, offering propositions, and comparing different points of view, which ultimately leads to develop awareness of one's own strengths and weaknesses.

Concerning learning from peers, which has been strongly emphasised by Vygotsky, $83 \%(\mathrm{M}=4.8)$ of the teachers agree with item (15) in that students learn best when they work with peers. This indirectly reveals the teachers' support to Vygotsky's ZPD, where students are expected to learn best and stretch their existing skills with the assistance of a more capable peer.

As for item (16), 36\% (M=1.82) of the teachers agree that students are more engaged and stay in touch with their teachers when they work alone; i.e., $64 \%$ of them disagree with it and believe that it is cooperative work that increases students' participation and keeps them more engaged.

As for the third domain, there is a general consensus among the teachers regarding the effectiveness of cooperative work.

The last domain of the questionnaire is concerned with utilising multi source materials. This domain includes seven items. Its first item is as follows:

Regarding item (17), we find that $84 \%(\mathrm{M}=4.24)$ agree that activities devised through the use of authentic and multisource materials enhance students' interest. This shows the teachers' view that the variety and assortment of the materials play a fundamental role in arousing students' interest towards learning the new language.

As for item (18), 85\% (M=4.27) agree that multisource materials improve students' EFL skills (including reading). This is a good indication that the teachers acknowledge the effectiveness of multisource materials in teaching EFL, which can be considered a positive indication in favour of the implementation of constructivism. 
Item (19) managed to get $82 \%(\mathrm{M}=4.27)$ of the teachers' agreement. It means that the majority of the teachers support utilising multisource materials in teaching EFL since these empower students to think in the target language. Hence, the use of multitude types of authentic materials which contain elements of the target culture can serve the broader educational aim of developing students' intercultural communicative competence.

As for item (20), 86\% (M=4.37) of the teachers agree that the students find multisource materials up to date and more stimulating. These materials maximise their chances of modernising their English and learn the language in its context of use which can be put to immediate and practical use in new situations.

$84 \%(\mathrm{M}=4.31)$ of the teachers agree with item (21), that multisource materials can help nurture students' language learning habits. This confirms that the teachers conceive multisource materials as a convenient way through which they can address the different learning habits of their students by making them inquisitive thinkers in the sense that the different representation of reality make students question and investigate the topic in depth and find out the reasons behind every phenomenon they study.

As for item (22), 82\% (M=4.24) agree that utilizing multisource materials is challenging due to syllabus constraints. The teachers admit that covering the prescribed syllabus is more difficult for teachers who utilise more than one material type and who intend to support their students to search and seek clear explanations.

Introducing materials from different sources into the curriculum cannot be done haphazardly. Teachers need to design some activities about these materials. As for item (23), $82 \%(\mathrm{M}=4.18)$ consider designing activities for these materials demanding in terms of preparation and administration. This entails that the teachers struggle when they design activities for their students, i.e. they are in need to take part in workshops and training programs so as to improve their skills in this respect.

The aim of the teachers' questionnaire was to gauge impressions of their educational experience. Owing to the small standard deviation (SD), ranging from (0.48) to (0.78) for the teachers' questionnaire items, it seemed that the teachers have agreement with each other. Accordingly, we find a commonality of interest and readiness among the teachers towards the implementation of constructivism.

The quantitative results obtained from the teachers' questionnaire about the principles of constructivism gave the impression that the Kurdish EFL teachers have positive perspectives towards implementing them. To put it differently, regarding the usefulness of utilising the principles of constructivism (namely: students as active agents in building knowledge, teachers as facilitators, authentic assessment, cooperative work, and multisource materials) in EFL classes, the majority of the teachers indicated their agreement with Constructivist principles.

To sum up, the above results confirm that Kurdish EFL teachers regard the implementation of constructivist principles as effective and productive, i.e. the have positive perspectives towards the implementation of constructivism in teaching EFL. This means that the fourth hypothesis which states that Kurdish University teachers have a neutral perspective towards implementing the principles of constructivism in teaching EFL to their students is rejected.

One of the issues that emerges from these positive results is the fact that Kurdish EFL teachers have shown readiness towards the implementation of constructivism, which can be regarded as an affirmative assertion that supports any future projects for implementing constructivism in the EFL departments at Salahaddin University. This result accords with Hassan's (2014) conclusion concerning EFL teachers at Salahaddin University-Erbil "that almost all the teachers are keenly engaged in the profession of teaching and make every endeavour to promote their students' skills".

An important point to be mentioned is that the real implementation of constructivism on the part of Kurdish EFL teachers remains unclear since the present study does not provide evidence for its real implementation by the participant teachers. The results show that all the participant teachers claimed that they agree with implementing constructivism in teaching EFL. This could be attributed to the fact that the teachers believe that they are expected to utilise the new pedagogies and practices in nowadays EFL classes, therefore they claim to do so. A decisive judgement cannot be made until this issue is settled by conducting a further study to investigate this issue.

The researcher supports her argument by referring to Unal and Akpınar's assertion, as cited in Cirik, Çolak, and Kaya (2015, p.37), where they state "although teachers have relatively positive perceptions on constructivist learning on theoretical level, in classroom settings they do not implement constructivist learning principles properly".

\section{CONCLUSION}

This study sought to draw out Kurdish EFL teachers' perspectives towards constructivism. Although the study did not reveal any evidence concerning the teachers' actual classroom practices, the majority of Kurdish EFL teachers at Salahaddin University-Erbil expressed an undoubted agreement with the use of constructivist principles in teaching EFL. Despite the fact that generalizations cannot be made for the whole body of Kurdish EFL teachers in KR, the results have the potential at least to help the educators to acquire perspective of EFL teaching in our universities. In any case, to a certain extent, it is legitimate to infer that Kurdish EFL teachers now have a justification to implement constructivism in their classes since they have shown signs of consent towards it.

\section{REFERENCES}

Astawa, N, Artini, L., and Nitiasih, K. (2017). Project-based learning activities and efl students' productive skills in English. Journal of Language Teaching and Research. 8 (6), pp.1147-1155.

Bakla, A. (2011). Teachers' views on constructivism in Turkish primary EFL classes. Mediterranean Journal of Humanities. 1 (2), pp. 1-20. 
Benson, Ph. (2011). Teaching and Researching Autonomy. US: Pearson Co. Brooks, J. and Brooks, M. (1999). In search of understanding: The case for constructivist classrooms. VA: Association for Supervision and Curriculum Development.

Cey, T. (2001). Moving Towards Constructivist Classrooms. University of Saskatchewan. Retrieved from https://etad.usask.ca/802papers/ceyt/ceyt.pdf

Chieu, V. M. (2005). Constructivist Learning: An Operational Approach for Designing Adaptive Learning Environments Supporting Cognitive Flexibility. A published PhD dissertation, Université catholique de Louvain.

Cirik, I., Çolak, A., and Kaya, D. (2015). Constructivist learning environments: the teachers' and students' perspectives. International Journal on New Trends in Education and Their Implications. 6 (2), pp.30-45.

Fernando, S. Y. and Marikar, F. M. (2017). Constructivist teaching/learning theory and participatory teaching methods. Journal of Curriculum and Teaching. 6 (1).

Fosnot, C. T. (2005). Constructivism revisited: Implications and reflections. In C. T. Fosnot (Ed.), Constructivism: Theory, Perspectives, and Practice. 2nd ed. (pp.276-292). New York: Teachers College.

Fox, R. (2001). Constructivism Examined. Oxford Review of Education. 27(1), pp. 23-35.

Hasan, H. S. (2014). An Assessment of the Sociocultural Approach to Teaching Communication at Salahaddin University. Unpublished MA thesis, Salahaddin University.

Henry, M. (2002). Constructivism in the community college classroom. History Teacher. 6 (1), pp. 65-74.

Hinojosa, L. M. M. (2015). Contributions of educational psychology to university education. Psychology. 6, pp.177-190.

Jordan, A., Carlile, O. and Stack, A. (2008). Approaches to Learning: A Guide for Teachers. London: McGraw-Hill House.

Kaufman, D. (2004). constructivist issues in language learning and teaching. Annual Review of Applied Linguistics. 24 (3), pp. 303-319.

Kaymakoğlu, S. (2014). Beliefs and practices of EFL teachers: constructivist or traditional. International Online Journal of Education and Teaching. 1 (3), pp.216-224.

Kudryashova, A., Gorbatova, T., Rybushkina, S., Ivanova, E. (2016). Teacher's roles to facilitate active learning. mediterranean Journal of Social Sciences. 7 (1).

Mahmud, A. (2013). Constructivism and reflectivism as the logical counterparts in TESOL: learning theory versus teaching methodology. TEFLIN Journal. 24 (2).

Richards, J. C. and Schmidt, R. (2010). Longman Dictionary of Language Teaching and Applied Linguistics. 3rd edition. London: Pearson Education Limited.

Rowell, C. G. and Palmer, B. C. (2007). Cognitive and Constructivist Strategies for Teaching about Language and for Providing Reading and Writing Instruction. Published by the Forum on Public Policy. Retrieved from https://files.eric.ed.gov/fulltext/EJ1099088.pdf

Schell, G. P. and Janicki, T. J. (2013). Online course pedagogy and the constructivist learning model. Journal of the Southern Association for Information Systems. 1 (1), pp.26-36.

Sengupta, A. (2016). Going beyond traditional assessment: alternative assessment and Indian ESL classroom. Humainising Language Teaching. Year 18, Issue 1.

Tan, C. (2016). Constructivism and pedagogical reform in China: Issues and challenges. Globalisation, Societies and Education. 10, pp.1-10.

Vadeboncoeur, J. A. (1997). Child development and the purpose of education: A historical context for constructivism in teacher education. In V. Richardson (ed.), Constructivist teacher education: Building new understandings. pp.15-37. London: The Falmer Press.

Wilson, B. and Cole, P. (1991). A review of cognitive teaching models. Educational Technology Research and Development. 39(4).pp. 4764.

Young, G. (2014). The Journey to Becoming Constructivist, Presidential Award for Excellence in Mathematics and Science Teaching, Secondary Mathematics Teacher. A published PhD dissertation. Portland State University.

\section{APPENDIX}

The descriptive analysis of teachers' questionnaires results

\begin{tabular}{|c|c|c|c|c|}
\hline No. & Item & Mean & SD & $\begin{array}{c}\% \text { of } \\
\text { agreement }\end{array}$ \\
\hline 1 & $\begin{array}{l}\text { Learners need to be active } \\
\text { participants in the learning } \\
\text { process. }\end{array}$ & 4.41 & 0.54 & 88.16 \\
\hline 2 & $\begin{array}{l}\text { Maximizing teacher-students } \\
\text { interaction reduces students' } \\
\text { shame and matures their } \\
\text { personality. }\end{array}$ & 4.18 & 0.49 & 83.67 \\
\hline 3 & $\begin{array}{l}\text { It is important to consider } \\
\text { students' voice and choice in } \\
\text { selecting materials/activities. }\end{array}$ & 4.20 & 0.58 & 84.08 \\
\hline 4 & $\begin{array}{l}\text { Acting the role of partner and } \\
\text { facilitator of knowledge with } \\
\text { students is favourable to me. }\end{array}$ & 4.41 & 0.61 & 88.16 \\
\hline 5 & $\begin{array}{l}\text { Assigning tasks/projects to } \\
\text { students can reveal their } \\
\text { uniqueness. }\end{array}$ & 4.33 & 059 & 86.53 \\
\hline 6 & $\begin{array}{l}\text { Assessing students through } \\
\text { dynamic assessment tools } \\
\text { rather than traditional tests is } \\
\text { stimulating for students. }\end{array}$ & 4.47 & 0.58 & 89.39 \\
\hline 7 & $\begin{array}{l}\text { Dynamic assessment can } \\
\text { show the students' efforts in } \\
\text { learning outside their } \\
\text { classrooms. }\end{array}$ & 4.27 & 0.45 & 85.31 \\
\hline 8 & $\begin{array}{l}\text { Dynamic assessment can } \\
\text { enrich students' learning } \\
\text { experience. }\end{array}$ & 4.16 & 0.48 & 83.27 \\
\hline 9 & $\begin{array}{l}\text { Traditional paper-based tests } \\
\text { decrease students' engagement } \\
\text { and willingness to learn. }\end{array}$ & 3.67 & 0.78 & 73.47 \\
\hline 10 & $\begin{array}{l}\text { Dynamic assessment is } \\
\text { flexible and provides students } \\
\text { with success opportunities. }\end{array}$ & 3.98 & 0.56 & 79.59 \\
\hline 11 & $\begin{array}{l}\text { Group work can increase } \\
\text { students' social interaction } \\
\text { skills. }\end{array}$ & 4.24 & 0.69 & 84.90 \\
\hline 12 & $\begin{array}{l}\text { Group work enables students' } \\
\text { to exchange experiences and } \\
\text { share ideas. }\end{array}$ & 4.31 & 0.51 & 86.12 \\
\hline 13 & $\begin{array}{l}\text { Group work leads students to } \\
\text { be autonomous and } \\
\text { responsible for their own } \\
\text { learning. }\end{array}$ & 4.35 & 0.60 & 86.94 \\
\hline 14 & $\begin{array}{l}\text { Group work helps students } \\
\text { diagnose their own strengths } \\
\text { and weaknesses. }\end{array}$ & 4.31 & 0.51 & 86.12 \\
\hline 15 & $\begin{array}{l}\text { Students learn best when they } \\
\text { work with peers. }\end{array}$ & 4.18 & 0.53 & 83.67 \\
\hline
\end{tabular}




\begin{tabular}{|c|c|c|c|c|}
\hline 16 & $\begin{array}{l}\text { Students are more engaged } \\
\text { and stay in touch with their } \\
\text { teachers when they work } \\
\text { alone. }\end{array}$ & 1.82 & 0.63 & 36.33 \\
\hline 17 & $\begin{array}{l}\text { Activities devised through the } \\
\text { use of authentic and } \\
\text { multisource materials increase } \\
\text { students' interest. }\end{array}$ & 4.24 & 0.48 & 84.90 \\
\hline 18 & $\begin{array}{l}\text { Multisource materials } \\
\text { improve students' EFL skills } \\
\text { (including reading). }\end{array}$ & 4.27 & 0.49 & 85.31 \\
\hline 19 & $\begin{array}{l}\text { Authentic materials broaden } \\
\text { students' understanding and } \\
\text { acquaintance with English } \\
\text { language use and culture. }\end{array}$ & 4.27 & 0.49 & 85.31 \\
\hline 20 & $\begin{array}{l}\text { Students find multisource } \\
\text { materials up to date and more } \\
\text { stimulating. }\end{array}$ & 4.37 & 4.49 & 87.35 \\
\hline 21 & $\begin{array}{l}\text { Multisource materials can } \\
\text { help nurture students' } \\
\text { language learning habits. }\end{array}$ & 4.31 & 0.51 & 86.12 \\
\hline 22 & $\begin{array}{l}\text { Utilizing multi-source } \\
\text { materials is challenging due to } \\
\text { syllabus constraints. }\end{array}$ & 4.24 & 0.50 & 84.90 \\
\hline 23 & $\begin{array}{l}\text { Designing activities for these } \\
\text { materials is demanding in } \\
\text { terms of preparation and } \\
\text { administration. }\end{array}$ & 4.18 & 0.60 & 83.67 \\
\hline
\end{tabular}

